\title{
SELF-SUFFICIENCY OPTIMIZATION OF STUDENTS LEARNING THROUGH MODULE
}

\author{
Atika Dwi Evitasari \\ IKIP PGRI Wates \\ atika.rania17@gmail.com
}

\section{Article History}

accepted 30/09/2018

approved $12 / 10 / 2018$

published 30/10/2018

\section{Keywords}

learning independent, teaching materials,

module.

\begin{abstract}
Students are unique individual. Primary students are individuals who have stages develope concrete operasional. They have conditional of study what on help understanding learning material. According to obvious until will creating procces of study purpose for participants of students and will impact for reached competences will expect. Additionally, other things what needed interest are learning independent. Learning independent is a learn attitude what not depend to ones, include to teacher for continue. Existence learning independent in students will appearence in active attitude to follow learn activity. Learning independent is depend to create and accustom early. A learning competence and independent in students will reached if teacher can created learn condition to approriote. One of them is arrange module material. Module is a complete unit what consist on structure learn activity what will arrange for help they for reached a number of purpose what will formula according to special and clear.
\end{abstract}

Social, Humanities, and Education Studies (SHEs): Conference Series

p-ISSN 2620-9284 https://jurnal.uns.ac.id/shes

e-ISSN 2620-9292 


\section{PENDAHULUAN}

Pendidikan adalah tema yang tidak bosan untuk dibahas. Kegiatan operasional pendidikan adalah proses pembelajaran di dalam kelas maupun di luar kelas. Pembelajaran merupakan suatu sistem. Pelaku utama dalam proses pembelajaran adalah peseta didik. Peserta didik merupakan individu yang unik. Artinya bahwa masing-masing individu adalah berbeda, mereka mempunyai karakter yang tidak sama, mempunyai kecepatan tahapan perkembangan yang tidak sama meskipun memiliki rentang usia yang hampir sama.

Dalam suatu sistem pembelajaran, peserta didik termasuk dalam komponen masukan (input). Sistem merupakan satu kesatuan berbagai unsur yang mempunyai hubungan fungsional dan berinteraksi secara dinamis untuk mencapai tujuan atau fungsi sistem tersebut (Atika Dwi Evitasari, 2015: 139). Sistem pembelajaran terdiri dari masukan (input), proses (process), keluaran (output), dan lulusan yang berhasil (outcome). Sudah disampaikan sebelumnya bahwa peserta didik termasuk ke dalam komponen masukan. Selain peserta didik, komponen masukan terdiri atas masukan instrumental dan masukan lingkungan. Masukan instrumental berupa kurikulum, bahan ajar, media, guru, sarana prasarana, dan sebagainya. Sedangkan masukan lingkungan terdiri atas lingkungan sosial dan lingkungan fisik dari peserta didik.

Ketiga komponen di atas akan saling berinteraksi pada suatu proses pembelajaran yang berlangsung di dalam kelas. Komponen masukan yang merupakan suatu sistem akan saling mempengaruhi satu dengan yang lainnya. Ketika komponen masukan dirancang dengan baik dan proses pembelajaran berjalan dengan baik maka akan diperoleh keluaran yang baik pula. Keluaran-keluaran tersebut berupa kompetensi-kompetensi yang harus dicapai oleh peserta didik yang berupa aspek koginitif, afektif, dan psikomotorik. Dalam kegiatan belajar, peserta didik akan memperoleh perubahan tingkah laku pada diri mereka. Perubahan tingkah laku tersebut didasari adanya perubahan kompetensi yang ada pada peserta didik.

Selain kompetensi, keluaran yang tidak kalah penting menjadi perhatian adalah karakter mandiri. Mandiri memiliki arti tidak tergantung kepada orang lain, bebas, dan dapat melakukan sendiri (Rusman, 2011: 353). Dengan kemandirian, peserta didik tidak tergantung kepada orang lain secara terus menerus dalam proses belajarnya. Kemandirian akan menciptakan suasana aktif belajar dari diri peserta didik karena adanya kemandirian akan memunculkan inisiatif dalam diri peserta didik untuk belajar. Kemandirian dalam belajar perlu ditanamkan semenjak dini agar kelak mereka bisa menjadi pribadi yang lebih percaya diri dalam mencapai tujuan hidup.

Pentingnya kemandirian belajar karena adanya peserta didik yang tidak percaya diri dengan kemampuannya sehingga ketika pelaksanaan ujian tidak sedikit diantara mereka membuat lembar contekan atau melihat dar jawaban dari temannya. Dalam proses pembelajaran yang berlangsung, beberapa mahasiswa masih belum mempunyai inisiatif dalam aktivitas pembelajaran. Mandiri merupakan salah satu karakter yang harus dimiliki oleh setiap individu. Kemandirian belajar dapat diperoleh dengan menanamkan, mengembangkan, dan membiasakan sikap tersebut kepada peserta didik. Hal yang bisa dilakukan guru untuk dapat membantu peserta didik menjadi pribadi yang mandiri dalam belajar adalah dengan merancang pembelajaran yang dapat membiasakan peserta didik belajar secara mandiri. Salah satunya dengan menggunakan bahan ajar yang tepat. Bahan ajar merupakan segala bentuk bahan yang dapat digunakan untuk menunjang kegiatan pembelajaran di kelas agar kompetensi-kompetensi atau keluaran (output) yang diinginkan dapat tercapai. Bahan ajar yang tepat untuk membantu peserta didik lebih mandiri dalam belajar satu diantaranya adalah modul.

Adanya modul yang disusun oleh guru diharapkan akan mampu mengoptimalkan kemandirian belajar peserta didik. Karena salah satu kelebihan modul adalah dapat menimbulkan suasana belajar mandiri (independent). Pada makalah ini akan 
dipaparkan terkait optimalisasi kemandirian belajar peserta didik melalui bahan ajar modul.

\section{Perkembangan Peserta Didik}

\section{PEMBAHASAN}

Setiap manusia mempunyai karakteristik yang berbeda, sehingga manusia dapat disebut dengan individu yang unik. Keunikan-keunikan inilah yang membedakan manusia yang satu dengan manusia lainnya. Tahapan perkembangan dialami oleh seluruh individu. Perkembangan tersebut tentu saja menuju kearah yang lebih baik. Perkembangan yang pesat dialami oleh individu usia Sekolah Dasar (SD). SD merupakan kegiatan pendidikan dasar yang ditempuh oleh individu sebelum kejenjang menengah. Pada usia SD anak-anak masih mempunyai rasa ingin tahu yang tinggi. Di SD terbagi menjadi dua tipe kelas, yaitu kelas rendah dan kelas tinggi. kelas rendah terdiri dari kelas satu, dua, dan tiga. Sedangkan, kelas tinggi terdiri dari kelas empat, lima, dan enam. Perkembangan pada tipe kelas tersebut mengikuti perkembangan seusia mereka.

Perkembangan mental yang menonjol pada usia SD adalah perkembangan fisik dan motorik, intelektual atau kognitif, bahasa, sosial, emosi, dan moral. Salah satu tahapan perkembangan yang menjadi perhatian guru dalam menerapkan pembelajaran yang tepat adalah tahapan perkembangan kognitif. Ada empat tahapan perkembangan individu yang dipaparkan oleh Jean Piaget yaitu: 1) tahap sensori motor (usia 0 sampai 2 tahun); 2) tahap pra operasional (usia 2 sampai 7 tahun); 3) tahap operasional konkret (usia 7 sampai 11 tahun); dan tahapan operasional formal (usia 11 keatas) (Sutirna, 2013: 28-29). Berdasarkan pernyataan Jean Piaget, maka usia anak SD masuk kedalam tahapan perkembangan operasional konkret.

Tahapan operasional konkret artinya proses berpikir anak masih konkret, belum bisa berpikir secara abstrak. Dengan demikian, pada tahapan ini peserta didik menyelesaikan masalah dengan menggunakan logika-logika yang abstrak atau bersifat fisik. Dalam penerapan di kelas guru dapat menghadirkan bendabenda nyata ke dalam proses pembelajaran atau mengkondisikan suasana belajar yang faktual. Pembelajaran merupakan suatu proses/ upaya menciptakan kondisi belajar dalam mengembangkan kemampuan minat dan bakat peserta didik secara optimal, sehingga kompetensi dan tujuan pembelajaran dapat tercapai (Atika Dwi Evitasari, 2017: 106).

\section{Kemandirian Belajar Peserta Didik}

Kata kemandirian berasal dari kata mandiri. Mandiri memiliki arti tidak tergantung kepada orang lain, bebas, dan dapat melakukan sendiri (Rusman, 2011: 353). Belajar dan pembelajaran sangat diperlukan kemandirian. Hal ini disebabkan guru tidak dapat secara terus menerus mendampingi peserta didik. Selain itu, dengan adanya kemandirian belajar pada diri peserta didik maka akan mendorong keaktifan peserta didik dalam belajar. Kemandirian biasanya ditandai dengan kemampuan menentukan nasib sendiri, kreatif dan inisiatif, mengatur tingkah laku, bertanggung jawab, mampu menahan diri, membuat keputusankeputusan sendiri, serta mampu mengatasi masalah tanpa ada pengaruh dari orang lain (Desmita, 2014: 185).

Kemandirian dalam belajar perlu diberikan kepada peserta didik supaya mereka mempunyai tanggung jawab dalam mengatur dan mendisiplinkan dirinya dan dalam mengembangkan kemampuan belajar atas kemauannya sendiri (Wedemeyer dalam Rusman, 2011: 354). Hal senada diungkapkan oleh Rathbone (Thanasoulas, 2000: 117) yang menyatakan bahwa kemandirian belajar adalah a self activated maker of meaning, and active agent in this own learning process. He 
is not one to whom things merrely happen: he is seen as the result of this own self initiated interaction with the world.

Steinberg dalam Desmita (2014: 186-187) membedakan karakteristik kemandirian dalam tiga bentuk, yaitu:

a. Kemandirian emosional, yakni aspek kemandirian yang menyatakan perubahan kedekatan hubungan emosional antar individu, seperti hubungan emosional peserta didik dengan guru atau dengan orang tuanya.

b. Kemandirian tingkah laku, yakni suatu kemampuan untuk membuat keputusan-keputusan tanpa tergantung kepada orang lain dan melakukannya secara bertanggung jawab.

c. Kemandirian nilai, yakni kemampuan memaknai seperangkat prinsip tentang benar dan salah, tentang apa yang penting dan apa yang tidak penting.

Kemampuan untuk membuat keputusan-keputusan yang telah disampaikan di atas jika dikaitkan dengan kemandirian belajar memiliki arti bahwa dalam setiap tindakan atau sikap yang dilakukan oleh peserta didik dalam proses pembelajaran merupakan insiatif sendiri tanpa ada perintah dari guru secara terus menerus.

Kemandirian merupakan salah satu karakter yang perlu ditanamkan dan dikembangkan dalam diri peserta didik. Peserta didik yang memiliki kemandirian adalah peserta didik yang aktif memberikan pemaknaan, seorang peserta didik yang aktif terhadap proses belajarnya. Dia bukanlah sasaran pembelajaran namun kemauannya sendirilah yang menyebabkan pembelajaran terjadi. Martinis Yamin (2008: 126) menambahkan bahwa kemandirian adalah memerlukan tanggung jawab, mereka yang mandiri adalah mereka yang bertanggung jawab, berinisiatif, memiliki keberanian, dan sanggup menerima dan mampu menjadi guru bagi dirinya sendiri. Berdasarkan beberapa pendapat yang telah disampaikan dapat ditarik kesimpulan bahwa kemandirian adalah sikap aktif yang dimiliki seseorang yang ditandai dengan perilaku bertanggung jawab berinisiatif, memiliki keberanian, dan sanggup menerima serta mampu menjadi guru bagi dirinya sendiri. Dapat dikatakan peserta didik yang aktif adalah peserta didik yang mandiri.

Kemandirian perlu ditanamkan sejak dini kepada seorang individu. Hal ini dimasudkan agar mereka dapat aktif dalam proses belajar mengajar di dalam kelas maupun di luar kelas. Dengan adanya kemandirian, peserta didik tidak mudah tergantung kepada guru atau orang lain secara terus menerus akan tetapi tidak berarti mereka belajar sendiri. Hal tersebut senada yang disampaikan oleh Panen (Rusman, 2011: 355) menyatakan, belajar mandiri tidak berarti belajar sendiri. Sangat jelas bahwa belajar mandiri tidak berarti belajar sendiri, dalam belajar mandiri peserta didik boleh bertanya, berdiskusi atau meminta penjelasan dari orang lain, akan tetapi tidak boleh menggantungkan diri dari bantuan, pengawasan, dan arahan dari orang lain termasuk guru secara terus menerus.

Kemandirian belajar dapat dilihat dari keaktifan belajar peserta didik di sekolah ataupun di rumah. Kemandirian belajar pada tiap tingkatan usia tergantung pada tahapan perkembangannya. Tingkat kemandirian belajar usia SD dan usia SMP serta SMA tidaklah sama. Ciri-ciri peserta didik yang mempunyai kemandirian menurut Flannagan (2008: 26) adalah “... would show resourcefulness, initiative and persistence in his or her self-directed learning activity". Jadi peserta didik yang mandiri akan menampakkan akal, inisiatif dan ketekunan dalam pembelajaran mandirinya.

Kemandirian sangat penting bagi peserta didik karena kondisi kompleksitas yang terjadi di lingkungan mereka tumbuh. Komplesitas tersebut berupa adanya pergaulan yang bebas, perkelahian antar pelajar, tindakan kriminal yang dilakukan 
oleh para pelajar, dan hal lain yang sering terjadi pada peserta didik. Kaitan kemandirian dengan proses belajar, adanya peserta didik yang tidak percaya diri dengan kemampuannya sehingga ketika pelaksanaan ujian tidak sedikit diantara mereka membuat lembar contekan atau melihat dar jawaban dari temannya. Dalam proses pembelajaran yang berlangsung, beberapa mahasiswa masih belum mempunyai inisiatif dalam aktivitas pembelajaran. Guru perlu memberikan perintah kepada peserta didik secara terus menerus untuk aktif dalam belajar.

Adanya fenomena-fenomena teseebut tugas guru sangatlah penting. Tugas guru dalam proses belajar mandiri adalah sebagai fasilitator yaitu menjadi orang yang siap member bantuan kepada peserta didik bila diperlukan. Hal terpenting dalam proses belajar mandiri adalah peningkatan kemampuan dan keterampilan peserta didik dalam proses belajar mengajar tanpa bantuan dari orang lain. Peserta didik dapat menyelesaikan tugas atau tes tanpa meminta bantuan jawaban dari teman, orang tua ataupun guru. Peserta didik mencari sendiri jawaban yang tepat.

\section{Peran Bahan Ajar Modul dalam Optimalisasi Kemandirian Belajar}

Adanya beberapa fenomena yang telah dipaparkan pada bagian sebelumnya, maka pendidikan di sekolah perlu melakukan upaya-upaya pengembangan kemandirian peserta didik. Menurut Desmita (2014: 190), upaya-upaya yang dapat dilakukan adalah sebagai berikut:

a. Mengembangkan proses belajar mengajar yang demokratis yang memungkinkan anak merasa dihargai.

b. Mendorong anak untuk berpartisipasi aktif dalam pengambilan keputusan dan dalam berbagai kegiatan di sekolah.

c. Member kebebasan kepada anak untuk mengeksplorasi lingkungan, mendorong rasa ingin tahu mereka.

d. Penerimaan positif tanpa syarat kelebihan dan kekurangan untuk tidak membeda-bedakan anak yang satu dengan yang lain.

e. Menjalin hubungan yang akarb dan harmonis dengan anak.

Hal di atas dapat terwujud jika guru dapat menciptakan situasi belajar yang mendukung. Banyak hal yang dapat dilakukan oleh guru, satu diantaranya dapat dengan menyusun bahan ajar yang dapat membantu mengembangkan kemandirian belajar kepada peserta didik.

Bahan ajar merupakan segala bentuk bahan yang digunakan untuk membantu guru/instruktur dalam melaksanakan kegiatan belajar mengajar (Abdul Majid, 2006: 173). Sebelum pembelajaran guru harus mempersiapkan segala bahan yang dibutuhkan guna mencapai tujuan pembelajaran. Bahan ajar merupakan informasi, alat, dan teks yang diperlukan guru dalam perencanaan dan penelaahan implementasi pembelajaran.

Suratsih (2010: 12) menyatakan bahwa bahan ajar adalah sumber belajar yang secara sengaja dikembangkan untuk tujuan pembelajaran. Jadi, bahan ajar sengaja disusun oleh guru agar kondisi belajar yang direncakan dapat tercapai. Bahan ajar bersifat sistematis artinya disusun secara urut sehingga memudahkan peserta didik dalam belajar. Bahan ajar juga bersifat unik dan spesifik. Unik berarti bahan ajar hanya digunakan pada sasaran dan dalam proses pembelajaran tertentu. Sedangkan spesifik mempunyai arti bahwa isi bahan ajar disusun sedemikian rupa hanya untuk mencapai kompetensi tertentu dari sasaran tertentu. Berdasarkan beberapa definisi bahan ajar yang sudah dipaparkan, dapat disimpulkan bahan ajar merupakan segala bentuk bahan yang disusun secara sistematis yang dapat membantu guru dan peserta didik dalam proses pembelajaran sehingga tujuan pembelajaran tercapai.

Bahan ajar mempunyai banyak jenis salah satunya adalah modul. Modul adalah salah satu jenis bahan ajar cetak (printed). Russel (Reed, 2001: 
60)menyatakan bahwa a module is an instructional package dealing with a single conceptual unit of subject matter. It is an attempt to individualize learning by enabling the student to master one unit of content before moving to another. Artinya, modul adalah suatu paket yang memuat satu unit konsep dari bahan pelajaran. Pembelajaran dengan modul merupakan usaha penyelenggaraan pembelajaran secara individual yang memungkinkan peserta didik menguasai satu unit pelajaran sebelum ia beralih pada unit berikutnya.

Modul adalah alat atau prasarana pembelajaran yang berisi materi, metode, batasan-batasan, dan cara mengevaluasi. Modul adalah satu unit program belajar mengajar yang terkecil yang secara terperinci mengaskan tujuan, topik, pokokpokok materi, peranan guru, alat-alat dan sumber belajar, lembar kerja, dan lembar evaluasi (Vembriarto, 1985: 47). Berdasarkan uraian sebelumnya dapat disimpulkan bahwa modul adalah suatu bahan ajar yang disusun secara sistematis dan menarik yang mencakup kompetensi, isi matrei, lembar kegiatan peserta didik, hingga evaluasi yang dapat digunakan secara mandiri maupun kelompok guna mencapai tujuan pembelajaran.

Sifat-sifat modul adalah 1) merupakan satu unit atau paket pembelajaran terkecil da terlengkap; 2) memuat rangkaian kegiatan belajar yang terencana dan sistematis; 3) memuat tujuan belajar (standar kompetensi dan kompetensi dasar) yang dirumuskan secara eksplisit dan spesifik; 4) memungkinkan bagi peserta didik untuk belajar mandiri (independent); dan 5) merupakan realisasi pengakuan perbedaan individual. Selain sifat, modul juga memiliki karakteristik yang membedakan modul dengan bahan ajar cetak lainnya, yaitu: 1) self instructional; 2) self contained; 3) stand alone; 4) adaptif; 4) user friendly; 5) konsistensi; dan 6) format.

Self instructional artinya bahwa melalui modul peserta didik mampu membelajarkan diri sendiri, tidak bergantung pada pihak lain. Sesuai dengan tujuan modul yaitu agar peserta didik mampu belajar mandiri. Self contained artinya seluruh materi pembelajaran dari satu kompetensi atau subkompetensi yang dipelajari terdapat di dalam satu modul yang utuh. Stand alone atau berdiri sendiri mempunyai arti bahwa modul yang dikembangkan tidak memerlukan bahan ajar lain. Modul dapat dikatakan adaptif jika menyesuaikan dengan perkembangan ilmu pengetahuan dan teknologi, serta fleksibel digunakan di berbagai tempat. Sedangkan, arti dari user friendly adalah setiap paparan informasi yang tampil bersifat membantu dan bersahabat.

Berdasarkan sifat dan karakteristik modul yang telah dipaparkan tersebut dapat diketahui bahwa modul dapat membantu peseta didik untuk belajar mandiri. Belajar sendiri tanpa tergantung kepada orang lain bahkan guru secara terus menerus. Kemandirian belajar peserta didik dapat diperoleh jika guru dapat menciptakan kondisi belajar yang mendukung. Salah satunya dengan menyusun bahan ajar modul yang tepat, yaitu modul yang sesuai dengan tahap perkembangan peserta didik dan prinsip-prinsip bahan ajar.

Beberapa kelebihan modul adalah sebagai berikut: 1) peserta didik dapat mencapai tujuan belajar secara baik dalam waktu yang sesuai dengan kecepatan dan kemampuannya; 2) peserta didik termotivasi untuk lebih aktif berpartisipasi dalam belajar, karena ia harus belajar dan menemukan sendiri konsep yang dipelajari; 3) modul dapat disusun menurut pola-pola yang sesuai dengan kemampuan peserta didik; 4) butir soal (evaluasi) dalam modul digunakan sebagai alat ukur keberhasilan peserta didik dalam mencepai tujuan; dan 5) modul dapat dikerjakan dan digunakan dalam berbagai situasi dan tempat. Sedangkan, kekurangan dari modul adalah 1) waktu pembelajaran yang telah ditentukan dalam kurikulum membatasi waktu belajar peserta didikuntuk menyelesaikan suatu paket 
belajar dimana peserta didik seharusnya bebas mengatur waktu belajarnya; 2) biaya relative besar untuk penyusunan dan penggandaan modul.

Kekurangan adalah suatu resiko yan lazim pada usaha peningkatan kualitas pembelajaran. Sebuah modul akan bermakna jika peserta didik mudah menggunakannya. Dengan demikian maka modul harus menggambarkam kompetensi dasar yang akan dicapai peserta didik, disajikan dengan menggunakan bahasa yang baik, komunikatif, menarik, dan dilengkapi dengan gambar. Modul yang disusun sesuai dengan perkembangan peserta didik.

\section{SIMPULAN}

Kemandirian adalah sikap aktif yang dimiliki seseorang yang ditandai dengan perilaku bertanggung jawab berinisiatif, memiliki keberanian, dan sanggup menerima serta mampu menjadi guru bagi dirinya sendiri. Dapat dikatakan peserta didik yang aktif adalah peserta didik yang mandiri. Tugas guru dalam proses belajar mandiri adalah sebagai fasilitator yaitu menjadi orang yang siap memberi bantuan kepada peserta didik bila diperlukan. Hal terpenting dalam proses belajar mandiri adalah peningkatan kemampuan dan keterampilan peserta didik dalam proses belajar mengajar tanpa bantuan dari orang lain. Kemandirian perlu ditanamkan dan dikembangkan semenjak dini. Hal tersebut dapat dilakukan melalui kegiatan pembelajaran di kelas.

Guru dapat memfasilitasi dengan cara menyusun bahan ajar yang sesuai yaitu modul. kelebihan modul adalah sebagai berikut: 1) peserta didik dapat mencapai tujuan belajar secara baik dalam waktu yang sesuai dengan kecepatan dan kemampuannya; 2) peserta didik termotivasi untuk lebih aktif berpartisipasi dalam belajar, karena ia harus belajar dan menemukan sendiri konsep yang dipelajari; 3) modul dapat disusun menurut pola-pola yang sesuai dengan kemampuan peserta didik; 4) butir soal (evaluasi) dalam modul digunakan sebagai alat ukur keberhasilan peserta didik dalam mencepai tujuan; dan 5) modul dapat dikerjakan dan digunakan dalam berbagai situasi dan tempat. Dengan penyusunan modul yang tepat maka akan tercipta suasana belajar yang aktif dan mandiri.

\section{DAFTAR PUSTAKA}

Abdul Majid. (2006). Perencanaan Pembelajaran. Bandung: PT. Remaja Rosdakarya.

Atika Dwi Evitasari. (2015). Bahan Ajar dalam Pembelajaran Tematik. Akademika Jurnal Ilmiah Kependidikan, Vol. 14, No. 1, 138-157.

Atika Dwi Evitasari. (2017). Perkembangan Peserta Didik Usia Sekolah Dasar dan Pembelajaran IPA. Dikdastika Jurnal IImiah Pendidikan Ke-SD-an, Vol. 4, No. 2, 103-111.

Desmita. (2014). Psikologi Perkembangan Peserta Didik. Bandung: PT. Remaja Rosdakarya.

Flannagan, Jenny Sue. (2008). A Study of Student Achievement Based on Atonomous Learning and Self Efficacy. Desertasi Doktor, tidak diterbitkan, Regent University.

Martinis Yamin. (2008). Desain Pembelajaran Berbasis Tingkat Satuan Pendidikan. Jakarta: Gaung Persada Pers.

Reed, P.,A. (2001). Learning Style and Laboratory Preference: A Study of Middle School Technology Education Teachers in Virginia. Journal of Technology Education, Vol. 13, No. 1, 59-70.

Rusman. (2011). Model-model Pembelajaran. Jakarta: Rajawali Pers.

Suratsih. (2010). Pengembangan Modul Pembelajaran Biologi Berbasis Potensi Lokal dalam Rangka Implementasi KTSP SMA di Yogyakarta. Yogyakarta: Universitas Negeri Yogyakarta. 
Sutirna. (2013). Perkembangan dan Pertumbuhan Peserta Didik. Yogyakarta: Andi Offset.

Thanasoulas, Dimitrios. (2000). Autonomy and Learning: An Epistemological Approach. Apllied Semiotics/Semiotique Applique, Vol. 4, No. 10, 115-131.

Vembriarto. (1985). Pengantar Pengajaran Modul. Yogyakarta: Yayasan Pendidikan Paramita. 